\title{
A new brain metalloendopeptidase which degrades the Alzheimer ß-amy- loid 1-40 peptide producing soluble fragments without neurotoxic effects
}

K.M. Carvalho,

M.S.F. França,

G.C. Camarão and A.F. Ruchon

\author{
Laboratório de Neurobiologia Molecular Humana \\ Departamento de Fisiologia e Farmacologia, \\ Centro de Ciências da Saúde, \\ Universidade Federal do Ceará, Fortaleza, CE, Brasil
}

\section{Correspondence \\ K.M. Carvalho \\ Laboratório de Neurobiologia \\ Molecular Humana \\ Departamento de Fisiologia \\ e Farmacologia, CCS, UFCE \\ Caixa Postal 3157 \\ Rua Cel. Nunes de Melo, 1127 60430-270 Fortaleza, CE \\ Brasil}

Presented at the XII Annual Meeting of the Federação de Sociedades de Biologia Experimental, Caxambu, MG, Brasil, August 27-30, 1997.

Research supported by CNPq, FINEP, FUNCAP, FAPESP and CAPES.

Received April 11, 1997 Accepted August 14, 1997

\begin{abstract}
A new metalloendopeptidase was purified to apparent homogeneity from a homogenate of normal human brain using successive steps of chromatography on DEAE-Trisacryl, hydroxylapatite and Sephacryl $\mathrm{S}-200$. The purified enzyme cleaved the $\mathrm{Gly}^{33}-\mathrm{Leu}^{34}$ bond of the 25-35 neurotoxic sequence of the Alzheimer B-amyloid 1-40 peptide producing soluble fragments without neurotoxic effects. This enzyme activity was only inhibited by divalent cation chelators such as EDTA, EGTA and $o$-phenanthroline $(1 \mathrm{mM})$ and was insensitive to phosphoramidon and captopril ( $1 \mu \mathrm{M}$ concentration), specific inhibitors of neutral endopeptidase (EC 3.4.24.11) and angiotensin-converting enzyme (EC 3.4.15.1), respectively. The high affinity of this human brain endopeptidase for $\beta$-amyloid $1-40$ peptide $(\mathrm{Km}=5 \mu \mathrm{M})$ suggests that it may play a physiological role in the degradation of this substance produced by normal cellular metabolism. It may also be hypothesized that the abnormal accumulation of the amyloid B-protein in Alzheimer's disease may be initiated by a defect or an inactivation of this enzyme.
\end{abstract}

The major component of the amyloid deposits in Alzheimer's disease is an extremely insoluble 39- to 42-amino acid peptide with a strong tendency to aggregate, known as amyloid B-protein (AßP). It has been shown that the 25-35 sequence of this peptide (...SNKGAIIGLM...) is the main factor responsible for its neurotoxic effects $(1,2)$. $\mathrm{A} ß \mathrm{P}$ is part of the hydrophobic domain of the Alzheimer $ß$-amyloid precursor protein (APP), an integral transmembrane protein which may be processed via two pathways:
Key words

- Brain metalloendopeptidase

- Alzheimer ß-amyloid

1-40 peptide

- Alzheimer's disease i) cleavage of APP within the AßP sequence by an enzyme not yet characterized called "secretase", producing soluble fragments, and ii) cleavage of APP by lysosomal enzymes resulting in intact $\mathrm{A} B \mathrm{P}$ that can precipitate to form amyloid plaques.

It was demonstrated that $\mathrm{A} ß \mathrm{P}$ is also produced by normal cellular metabolism, but the proteases involved in its physiological degradation are not known (3-8).

In the present study, a new metalloendopeptidase which hydrolyzes AßP producing 
soluble fragments by a major cleavage of the Gly $^{33}$-Leu $^{34}$ bond of its 25-35 neurotoxic sequence was purified and characterized from the soluble fraction of normal human brain.

The brains obtained from three normal subjects (6 to $8 \mathrm{~h}$ after death in traffic accidents) aged 20 to 30 and kept at $-80^{\circ} \mathrm{C}$ were homogenized in 4 volumes (w/v) of $50 \mathrm{mM}$ Tris- $\mathrm{HCl}, \mathrm{pH} 7.5$, and centrifuged at 25,000 $g$ for $60 \mathrm{~min}$ at $4^{\circ} \mathrm{C}$. The pellet was discarded and the supernatant was exhaustively dialyzed against the same buffer used for brain homogenization. A volume of 1 liter of the dialyzed supernatant was applied to a DEAETrisacryl column $(2.6 \times 50 \mathrm{~cm})$ equilibrated with $50 \mathrm{mM}$ Tris- $\mathrm{HCl}, \mathrm{pH} 7.5$, at a flow rate of $90 \mathrm{ml} / \mathrm{h}$. After sample application, the column was developed with steps of $50 \mathrm{mM}$ Tris- $\mathrm{HCl}, \mathrm{pH} 7.5$, containing $\mathrm{NaCl}$ at the following concentrations: $50 \mathrm{mM}, 100 \mathrm{mM}$, $150 \mathrm{mM}, 300 \mathrm{mM}$ and $1000 \mathrm{mM}$. The fractions eluted with $50 \mathrm{mM} \mathrm{NaCl}$ containing the enzyme activity were pooled and concentrated to $10 \mathrm{ml}$ in a dialysis tube under reduced pressure. This sample was exhaustively dialyzed against $10 \mathrm{mM}$ potassium phosphate, $\mathrm{pH} 7.5$, and applied to a hydroxylapatite column $(2.5 \times 10 \mathrm{~cm})$ equilibrated against the same buffer. The column was eluted with a $10-500 \mathrm{mM}$ linear potassium phosphate gradient, $\mathrm{pH} 7.5$, at a flow rate of $30 \mathrm{ml} / \mathrm{h}$. Enzymatically active frac-

Table 1 - Purification of human brain metalloendopeptidase.

The enzyme activity was evaluated in 20- $\mu$ l aliquots from each purification step; $\left[\mathrm{dArg}{ }^{8}\right]$ kermit was used as substrate. Activities are reported as nmol peptide cleaved at the Ser-Phe bond per hour. Specific activity is reported as nmol substrate cleaved per hour per mg protein.

\begin{tabular}{lccccc}
\hline Step & $\begin{array}{c}\text { Total } \\
\text { protein } \\
(\mathrm{mg})\end{array}$ & $\begin{array}{c}\text { Total } \\
\text { activity } \\
(\mathrm{nmol} / \mathrm{h})\end{array}$ & $\begin{array}{c}\text { Specific } \\
\text { activity } \\
\left(\mathrm{nmol} \mathrm{h}^{-1} \mathrm{mg}^{-1}\right)\end{array}$ & $\begin{array}{c}\text { Purification } \\
\text { (times) }\end{array}$ & $\begin{array}{c}\text { Yield } \\
\text { (\%) }\end{array}$ \\
\hline Homogenate & 11300 & 63906 & 5.6 & 1 & 100 \\
Supernatant & 6690 & 51426 & 7.7 & 1.4 & 80 \\
DEAE-Trisacryl & 237 & 30855 & 13 & 23.2 & 48 \\
Hydroxylapatite & 8 & 18485 & 2310 & 412.5 & 29 \\
Sephacryl S-200 & 0.1 & 10057 & 10057 & 1796 & 16
\end{tabular}

tions were pooled, concentrated and exhaustively dialyzed against $50 \mathrm{mM}$ Tris- $\mathrm{HCl}, \mathrm{pH}$ 7.5. Finally, this sample was further fractionated on a Sephacryl S-200 column $(2 \mathrm{x}$ $160 \mathrm{~cm}$ ) equilibrated against the same dialysis buffer and developed at a flow rate of 60 $\mathrm{ml} / \mathrm{h}$. Fractions containing enzyme activity were concentrated and stored at $4^{\circ} \mathrm{C}$. Under such conditions, the purified enzyme was stable for over 3 months. A summary of the purification procedure is presented in Table 1.

Enzyme activity was monitored using as substrate the diaminobenzylthiocyanate (DABTC) derivative of $\left[\mathrm{dArg}^{8}\right]$ kermit, a derivate of kermit (Asp-Val-Asp-Glu-ArgAsp-Val-Arg-Gly-Phe-Ala-Ser-Phe-Leu$\mathrm{NH}_{2}$ ) that undergoes a single cleavage at the Ser-Phe bond, as described previously (9). This assay was chosen because it was used previously with success to monitor the purification of another metalloendopeptidase (peptide hormone inactivating enzyme, PHIE) from the skin granular gland secretions of Xenopus laevis which also hydrolyzed AßP with high affinity (9). Protein content was evaluated by the method of Bradford (10).

The purity of the enzyme was demonstrated by polyacrylamide gel electrophoresis: i) under nondenaturing conditions showing a single protein band coinciding with the enzyme activity, and ii) under denaturing conditions (heating at $100^{\circ} \mathrm{C}$ in the presence of $1 \%$ SDS and 10\% ß-mercaptoethanol) also showing a single protein band with an apparent molecular weight of $200 \mathrm{kDa}$ (data not shown).

The effects of various classical protease inhibitors on the enzyme activity were tested (data not shown). The serine- (PMSF, STI, TPCK and aprotinin), cystine- (PCMPS, PCMB and NEM), and carboxyl- (pepstatin and GEMSA) protease inhibitors, at $1 \mathrm{mM}$ concentration, did not inhibit the enzyme activity. However, metalloprotease inhibitors such as EDTA, EGTA and $o$-phenan- 
throline, at $1 \mathrm{mM}$ concentration, totally inhibited the enzyme activity, suggesting a metalloendopeptidase nature of the enzyme. Furthermore, phosphoramidon and captopril, specific inhibitors of neutral endopeptidase (EC 3.4.24.11) and angiotensin-converting enzyme (EC 3.4.15.1), respectively, did not inhibit the enzyme at micromolar concentrations.

The metalloendopeptidase performed a major cleavage of the Gly ${ }^{33}-\mathrm{Leu}^{34}$ bond of the 25-35 neurotoxic sequence of AßP producing soluble fragments without neurotoxic effects (Figure 1). The $\mathrm{Km}$ value for the enzyme-catalyzed hydrolysis of AßP was 5 $\mu \mathrm{M}$ (data not shown). This result shows the high affinity of the metalloendopeptidase for $\mathrm{A} B \mathrm{P}$.

During the last three years, several lines of evidence have suggested that AßP plays a key role in the process of plaque formation in Alzheimer's disease brain tissue $(1,2,10)$. Although the enzymes involved in the major steps of AßP processing have not been identified, the protease activities that mediate these cleavage events are called $\beta-$ and $\gamma$ secretase $(11,12)$. Furthermore, another protease activity called $\alpha$-secretase is not involved in the formation of $\mathrm{A} \beta \mathrm{P}$ and cleaves within the ABA domains of APP between Lys $^{612}$ and Leu ${ }^{613}$ producing soluble peptides. The true $\alpha$-secretase has yet to be identified. APP, which escapes $\alpha$-secretase cleavage, is endocytosed and degraded in the endosomes and lysosomes by $\beta$ - and $\gamma-$ secretases producing AßP (11-13).

It was demonstrated that $\mathrm{A} ß \mathrm{P}$ is also produced by normal cellular metabolism (38). However, the proteases involved in the physiological degradation of this peptide are not known. It is clear that these enzymes are very important to avoid the accumulation of

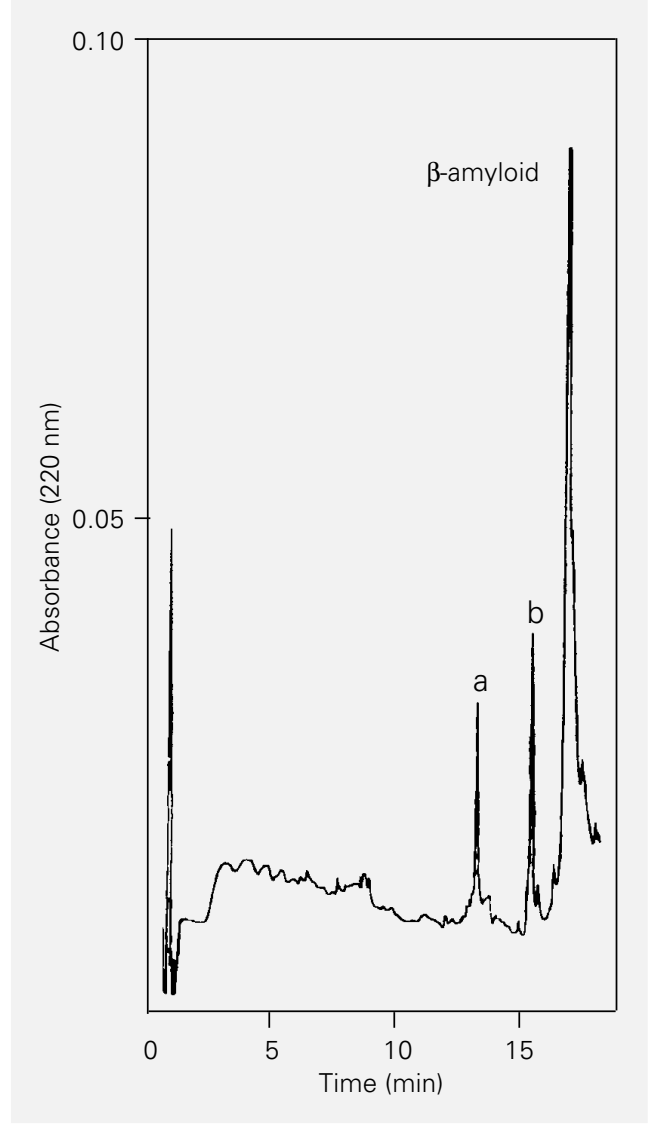

$\mathrm{A} ß \mathrm{P}$ in normal human brain. In the present study, we purified a new metalloendopeptidase from normal human brain that degrades $\mathrm{A} ß \mathrm{P}$ within its neurotoxic sequence, producing soluble fragments without neurotoxic effects. The high affinity of this endopeptidase by the $\mathrm{A} B \mathrm{P}(\mathrm{Km}=5 \mu \mathrm{M})$ suggests that it may play a physiological role in the degradation of this substance produced by normal cellular metabolism. It may also be hypothesized that the abnormal accumulation of $\mathrm{A}$ P in Alzheimer's disease may be initiated by a defect or an inactivation of this enzyme.

Further studies will be necessary to elucidate the primary structure of this enzyme and to better understand its possible physiological role in AßP degradation.
Figure 1 - HPLC elution profile of products of $ß$-amyloid 1-40 peptide generated after incubation with human brain metalloendopeptidase. The substrate $(20$ nmol) was incubated with $5 \mu$ of the purified enzyme in a final volume of $50 \mu \mathrm{l} 50 \mathrm{mM}$ Tris- $\mathrm{HCl}$ buffer, $\mathrm{pH} 7.5$, for $30 \mathrm{~min}$ at $37^{\circ} \mathrm{C}$. After centrifugation at $10,000 \mathrm{~g}$ for $10 \mathrm{~min}$, the supernatant fraction was injected into an HPLC column (Nucleosil $5 \mu \mathrm{m}$ $\mathrm{C}_{18} 145 \times 4.5 \mathrm{~mm}$ ) eluted with a 0-50 gradient of acetonitrile containing $0.05 \%$ TFA, over a period of $20 \mathrm{~min}$ at a flow rate of 1 $\mathrm{ml} / \mathrm{min}$. Fragments were identified by amino acid composition: $a$ and $b$ are the 1-33 and 34-40 fragments of $ß$-amyloid 1-40, respectively. 


\section{References}

1. Yankner BA, Duffy LK \& Kirschner DA (1990). Neurotrophic and neurotoxic effects of amyloid beta protein: reversal by tachykinin neuropeptides. Science, 250: 279-282.

2. Hardy JA \& Higgins GA (1992). Alzheimer's disease: the amyloid cascade hypothesis. Science, 256: 184-185.

3. Haass $C$, Schlossmacher MG, Hung AY, Vigo-Pelfrey C, Melon A, Ostaszewski BL, Lieberburg I, Koo EH, Schenk D, Teplow DB \& Selkoe DJ (1992). Amyloid betapeptide is produced by cultured cells during normal metabolism [see comments]. Nature, 359: 322-325.

4. Haass $C$, Hung AY, Schlossmacher MG, Oltersdorf TT, Teplow DB \& Selkoe DJ (1993). Normal cellular processing of the beta-amyloid precursor protein results in the secretion of the amyloid beta peptide and related molecules. Annals of the New York Academy of Sciences, 695: 109-116.

5. Shoji M, Golde TE, Ghiso J, Cheung TT, Estus S, Shaffer LM, Cai X, McKai DM, Tintner R, Frangione B \& Younkin SG (1992). Production of the Alzheimer amyloid beta protein by normal proteolytic processing. Science, 258: 126-129.
6. Busciglio J, Gabuzda DH, Matsudaira P \& Yankner BA (1993). Generation of betaamyloid in the secretory pathway in neuronal and nonneuronal cells. Proceedings of the National Academy of Sciences, USA, 90: 2092-2096.

7. Suzuki N, Cheung TT, Cai XD, Odaka A, Otvos Jr L, Eckman C, Golde TE \& Younkin SG (1994). An increased percentage of long amyloid beta protein secreted by familial amyloid beta protein precursor (beta APP717) mutants. Science, 264: 1336-1340.

8. Fuller SJ, Storey E, Li QX, Smith Al, Beyreuther K \& Masters CL (1995). Intracellular production of beta A4 amyloid of Alzheimer's disease: modulation by phosphoramidon and lack of coupling to the secretion of the amyloid precursor protein. Biochemistry, 34: 8091-8098.

9. Carvalho KM, Joudiou C, Bousseta $H$, Leseney AM \& Cohen P (1992). A peptide-hormone-inactivating endopeptidase in Xenopus laevis skin secretion. Proceedings of the National Academy of Sciences, USA, 89: 84-88.
10. Bradford MM (1976). A rapid and sensitive method for the quantitation of microgram quantities of protein utilizing the principle of protein-dye binding. Analytical Biochemistry, 72: 248-254.

11. Klafki HW, Abramowski RS, Paganetti PA \& Staufenbiel M (1996). The carboxyl termini of beta-amyloid peptides 1-40 and 142 are generated by distinct gammasecretase activities. Journal of Biological Chemistry, 271: 28655-28659.

12. Citron M, Diehl TS, Gordon G, Biere AL, Seubert P \& Selkoe DJ (1996). Evidence that the 42- and 40-amino acid forms of amyloid beta protein are generated from the beta-amyloid precursor protein by different protease activities. Proceedings of the National Academy of Sciences, USA, 93: 13170-13175

13. Saftig $P$, Peters $C$, Figura KV, Craessaerts K, Leuvens FV \& Strooper D (1996). Amyloidogenic processing of human amyloid precursor protein in hippocampal neurons devoid of cathepsin D. Journal of Biological Chemistry, 271: 27241-27244. 